\title{
Detection of the Predominant Strain of Epstein-Barr Virus in Systemic Autoimmune and Thalassemia Patients
}

\author{
Alaa Y. Al-Hamadany* \\ Technical Institute \\ Mosul
}

*Email:alaa.mahdy156@yahoo.com

\author{
Basima A. Abdullah \\ Department of Biology \\ College of Science \\ University of Mosul
}

(Received 9/6/2013;Accepted 9/9/2013)

\begin{abstract}
EBV, is a member of the herpesvirus family and one of the most common human viruses, Epidemiological data suggest that EBV is associated with polytransfused blood $\beta$ thalassemia and several autoimmune diseases, such as systemic lupus erythematosus, rheumatoid arthritis and multiple sclerosis. We examined the presence of IgM antibodies against EBV in serum of 35 Thalassemic patients, 75 autoimmune patients among as 35 rheumatoid arthritis patients, 20 Systemic lupus erythrematosus and 20 autoimmune hypothyroid diseases, and 20 healthy controls by ELISA assay then detected the predominant strain in positive samples. The results show that the highest EBV infection percent was in SLE 15\% whilst the lowest infection percent was in Thalassemia 5.7\%., and according to gender, the results showed that the highest infection percentage recorded in females with rheumatoid arthritis $30 \%$, whilst the infection does not appear in males with rheumatoid arthritis and autoimmune thyroid disease and females of thalassemia patients. On the other hand, this study reveals that EBV-1 is the predominant strain in autoimmune diseases and thalassemia in Iraq.
\end{abstract}

Keywords: EBV, Thalassemia, Autoimmune diseases.
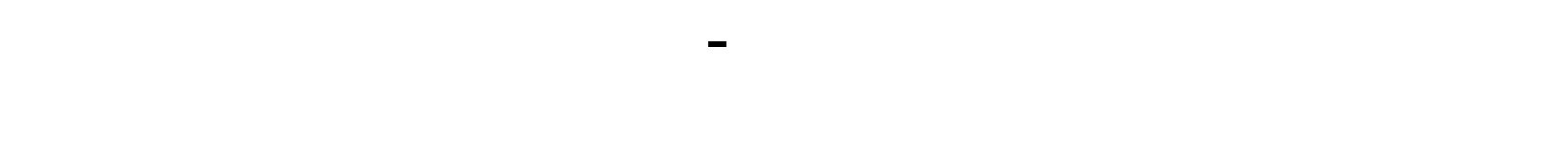

\section{المالغص}

لبشتان - بار فايروس هو لحد افراد عائلة Herpesvirus، ويعد من الفيروست اللثائعة في الإنسان.

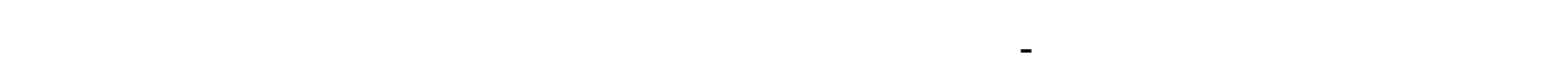

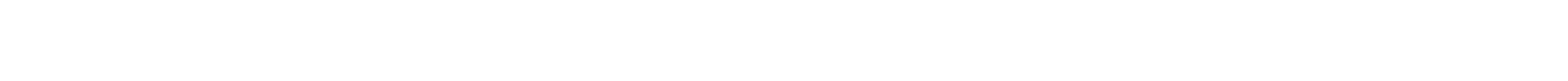

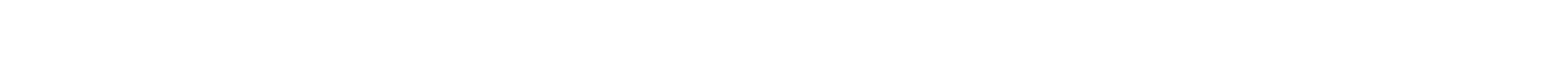

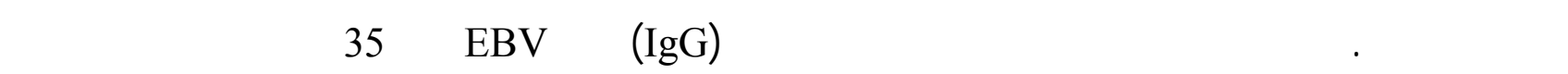


الثلاسيميا، 75 من مرض المناعة الذاتية موزعة بين 35 مريضا بالتهلب المفاطل الرثولني، داء النئب الحمراري 20 و 20 الأمراض المناعة الذلتية للغة الدرقية، و 20 الاصحاء بولنطة

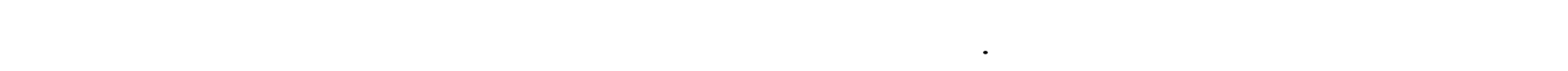

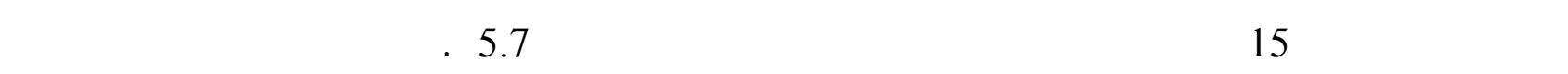

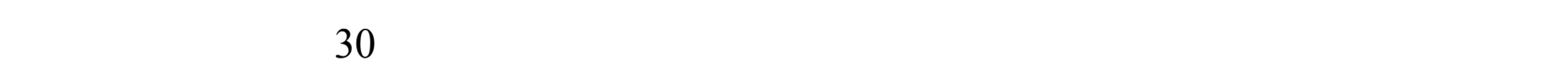

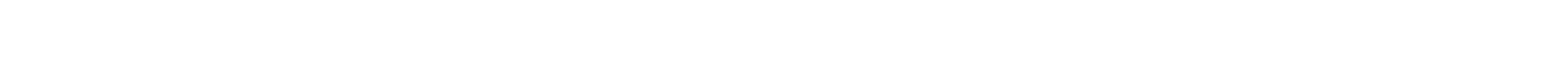
الثلاسيميا.من جهة لخرى كثفت هذه الدرلسة أن EBV-1 هي اللسلالة للسائية في أمراض المناعة الذاتية والثلمسيميا في العراق. الكاملت الدالة: لبشتاين - بار فايروس، فقر دم البحر المتوسط، أمراض المناعة الذاتية.

\section{INTRODUCTION}

Epstein-Barr virus (EBV) is a ubiquitous double stranded DNA virus from human herpes virus family, which has B-lymphotropism. More than $90 \%$ of adults in the world have serologic evidence of infection with this virus. It is acquired during early childhood and the age of infection is much lower in undeveloped countries with low socioeconomic condition (Rickinson and Kieff, 2001). A typical EBV virion consists of a linear doublestrand DNA genome packaged into an icosahedral capsid, which is surrounded by a proteinaceous structure called the tegument, and an envelope composed of several viral glycoproteins embedded in a lipid bilayer (Morissette and Flamand, 2010). It is replicated during each cell division by the host DNA polymerase together with the host chromosomes. The EBV genome encodes over 85 open reading frames ORFs (Kieff and Liebowitz, 2001).

EBV has been associated with a number of diseases, such as Hodgkin's lymphoma, Burkitt's lymphoma, nasopharyngeal carcinoma, conditions associated with human immunodeficiency virus HIV (Balandraud et al., 2004) and multiple transfused beta Thalassemia (Ergazaki et al., 1994) also associated with some non-B cell malignancies like extranodal T-cell and NK cell lymphomas, nodal T-cell lymphomas, nasopharyngeal carcinoma (NPC), gastric carcinoma and some others (Middeldorp et al., 2003) indicating the capacity of EBV to infect non-B cells as well.

EBV was first associated with autoimmune diseases in 1971, when a high prevalence of the virus was found in the sera of systemic lupus erythematosus (SLE) patients (Evans, 1971). Over the years, this relationship was strongly established, and today it is known that EBV infection preceding the development of autoimmune diseases may contribute to the pathogenesis of SLE via the mechanism of molecular mimicry of its nuclear antigen 1 (EBV NA-1) and lupus-associated autoantibodies (ANAs), and its subtypes such as anti-Sm and anti-Ro.(Poole et al., 2006). Aside from SLE, EBV infection is currently associated with multiple chronic autoimmune diseases such as rheumatoid arthritis (RA), multiple sclerosis (MS), Sjogren's syndrome (SS), autoimmune thyroiditis, and autoimmune hepatitis. (Pender, 2003)

The aim of this study is to indicate the presence of EBV antibody in the serum of some systemic autoimmune diseases and thalassemia patients and to know the predominant strain 
of EBV in a common autoimmune disorders and thalassemia by using ELISA and PCR techniques.

\section{Patients}

\section{MATERIALS AND METHODS}

A cohort of 130 serum samples has been collected of different autoimmune diseases as (RA, SLE, and ATD), Thalassemia and controls. Among those samples have been 35 RA, 20 SLE, 20 ATD, 35 thalassemia and 20 control samples, which were paid a visit Al-Salam Teaching, Ibn-Atheer Teaching and Nuclear medicine hospitals from date of $15 \backslash 8 \backslash 2012$ to $15 \backslash 2 \backslash 2013$ and diagnosed by the treating physicians and confirm the diagnosis by specific tests for each disease. Their ages are ranging from 3- 84 years.

\section{Methods}

A primary detection of EBV in all samples has been done by using Anti-EBV-CA ELISA (IgM) kit (Euroimmune, Germany), which provides a semi-quantitative in vitro assay for human anti-bodies of IgM class against Epstein Barr Virus capsid antigen (EBV-CA) in serum or plasma. In brief, the first reaction steps, diluted patient samples are incubated for 30 minutes in wells then wash three times used $300 \mu \mathrm{l}$ of working wash buffer and empty the wells. In the case of positive samples, specific IgM antibodies will bind to antigens. To detect the bound antibodies, a second incubation has been carried out after adding conjugate enzyme (peroxidase-labelled anti-human IgM) into each well, after wash $100 \mu \mathrm{l}$ of substrate was added into microplate wells and incubated in dark for 15 minutes at room temperature then finally stopped the reaction and read the absorbance at $450 \mathrm{~nm}$ within 30 minutes by using Microelisa (washer and reader) applied by Biotek, USA in Al-Salam Teaching hospital. The result is evaluated semi-quantitatively by calculating a ratio of the extinction value of the control or patient sample over the extinction value of calibrator by using the following formula to calculate the ratio:

\section{Ratio $=$ Extinction of the control or patient sample}

Interpreting result as following:

Extinction of calibrator

Ratio $<0.8$ : Negative

Ratio $>0.8<1.1$ : Borderline

Ratio > 1.1: Positive

\section{Viral DNA extraction}

The Geneaid Viral DNA extraction kit (Geneaid, USA) has been used for quickly and conveniently extract of DNA from serum. The method has been comprised of concentrating viral particles from serum, lysis of viral particles, viral DNA binding to the surface of the glass fiber membrane, and releasing of DNA into the release buffer. DNA extraction was done for 10 positive serum samples of Anti-EBV-CA ELISA (IgM) and the DNA concentration has been measured using a (Genova- Nano Spectrophotometer, Jenway) with nuclease free water used to reset the machine. The Abs 260 of the dsDNA has been measured and the concentration has been calculated. 


\section{Conventional PCR}

AccuPower PCR PreMix has been used to screen EBV for the presence of EBNA2 regions, as to the supplier's instructions (Bioneer, South Korea). This premix consists of a lyophilized pellet of $1 \mathrm{U}$ Top DNA polymerase, $250 \mu \mathrm{M}$ dNTP (dATP, dCTP, dGTP, and dTTP), $10 \mathrm{mM}$ Tris- $\mathrm{HCl}(\mathrm{pH} 9.0), 30 \mathrm{mM} \mathrm{KCl}, 1.5 \mathrm{mM} \mathrm{MgCl}$, a tracking dye, and a stabilizer and DNA in a final volume of $20 \mu \mathrm{l}$ Table(1).

Table 1: Primers of EBV (Synthesized by Bioneer)

\begin{tabular}{|c|c|c|c|}
\hline Primer name & orientation & Sequences(5́ -3́) & $\begin{array}{c}\text { Amplicon size } \\
\text { (bp.) }\end{array}$ \\
\hline \multirow{2}{*}{ EBNA2 } & Forward & AGG CTG CCC ACC CTG AGG AT & $\begin{array}{l}\text { type-1EBV 168 } \\
\text { type-2EBV 184 }\end{array}$ \\
\cline { 2 - 3 } & Reverse & GCC ACC TGG CAG CCC TAA AG & \\
\hline
\end{tabular}

Accomplished by Jin et al., 2010

PCR has been carried out on a Thermo cycler ( ${ }^{3}$ Prime Thermal Cycler, Techne). The reaction consists of an initial denaturation step $95^{\circ} \mathrm{c}, 5$ minutes, followed by 35 cycles of denaturation $95^{\circ} \mathrm{c}, 45$ seconds, annealing $56^{\circ} \mathrm{C}, 45$ seconds and elongation $72^{\circ} \mathrm{C}, 1$ minute. A final elongation step $72^{\circ} \mathrm{C}, 10$ minutes have been followed by cooling to $4^{\circ} \mathrm{c}$ before visualization on a $\%$ (w/v) agarose gel (Jin et al., 2010).

\section{Agarose Gel Electrophoresis}

Agarose has been dissolved in the appropriate volume of TBE buffer by heating in a hotplate stirrer. Ethidium bromide to a final concentration of $100 \mu \mathrm{g} / \mathrm{l}$ has been added to the molten gel to allow visualization of the DNA. Samples are loaded into the set gel, and run at $100 \mathrm{~V}$ in TBE for 1 hour. The nucleic acid bands have been visualized on a UV transilluminator.

\section{RESULTS}

According to ELISA technique, the results revealed that 10 of the patients have seropositive of EBV (Table 2) and the highest EBV infection percent was in SLE 15\% followed by ATD 10\% and RA $8.6 \%$ while the lowest infection percent was in Thalassemia $5.7 \%$ as (Table 3 ).

Table 2: EBV seropositive in study group

\begin{tabular}{|c|c|c|c|c|c|}
\hline Study groups & RA & SLE & ATD & Thala & Cont. \\
\hline $\begin{array}{c}\text { EBV } \\
\text { seropositive } \\
\text { (No.) }\end{array}$ & 3 & 3 & 2 & 2 & - \\
\hline Total & \multicolumn{5}{|c|}{10} \\
\hline
\end{tabular}

Thala $=$ Thalassemia, R.A $=$ Rheumatoid arthritis, $\mathrm{ATD}=$ Autoimmune thyroid disease, SLE= Systemic Lupus Erythromatosis, Cont.= control 
Table 3: Percentage of EBV seropositive in study group

\begin{tabular}{|c|c|c|c|c|c|}
\hline Study groups & RA & SLE & ATD & Thala & Cont. \\
\hline $\begin{array}{c}\text { EBV } \\
\text { seropositive } \\
(\%)\end{array}$ & 8.6 & 15 & 10 & 5.7 & - \\
\hline Total cases & 35 & 20 & 20 & 35 & 20 \\
\hline
\end{tabular}

Thala $=$ Thalassemia, R.A $=$ Rheumatoid arthritis, ATD $=$ Autoimmune thyroid disease, SLE $=$ Systemic Lupus Erythromatosis, Cont.= control

On the other hand, the results according to gender showed that the highest infection percentage recorded in females with rheumatoid arthritis $30 \%$, followed by females with SLE, autoimmune thyroid diseases and males of thalassemia patients $20 \%$ and the lowest infection percentage in male with SLE 10\%, while no infection in males with rheumatoid arthritis and autoimmune thyroid disease and females of thalassemia patients (Table 4).

Table 4: Percentage seropositivly EBV infection in relation to gender

\begin{tabular}{|c|c|c|c|c|c|}
\hline \multirow{2}{*}{$\begin{array}{c}\text { Study } \\
\text { Gender }\end{array}$} & Thala & RA & SLE & ATD & Total \\
\cline { 2 - 6 } & \multicolumn{5}{|c|}{ N0. (\%) } \\
\hline Males & $2(20 \%)$ & $0(0 \%)$ & $1(10 \%)$ & $0(0 \%)$ & $3(30 \%)$ \\
\hline Females & $0(0 \%)$ & $3(30 \%)$ & $2(20 \%)$ & $2(20 \%)$ & $7(70 \%)$ \\
\hline Total & $2(20 \%)$ & $3(30 \%)$ & $3(30 \%)$ & $2(20 \%)$ & $10(100 \%)$ \\
\hline
\end{tabular}

The frequency of type 1 or type $2 \mathrm{EBV}$ infection has been determined for all positive samples of the study groups. Collectively, type $1 \mathrm{EBV}$ is present in 9 of 10 positively samples $90 \%$ while type $2 \mathrm{EBV}$ is not found in samples $0 \%$ and one sample was missed (Fig. 1). 


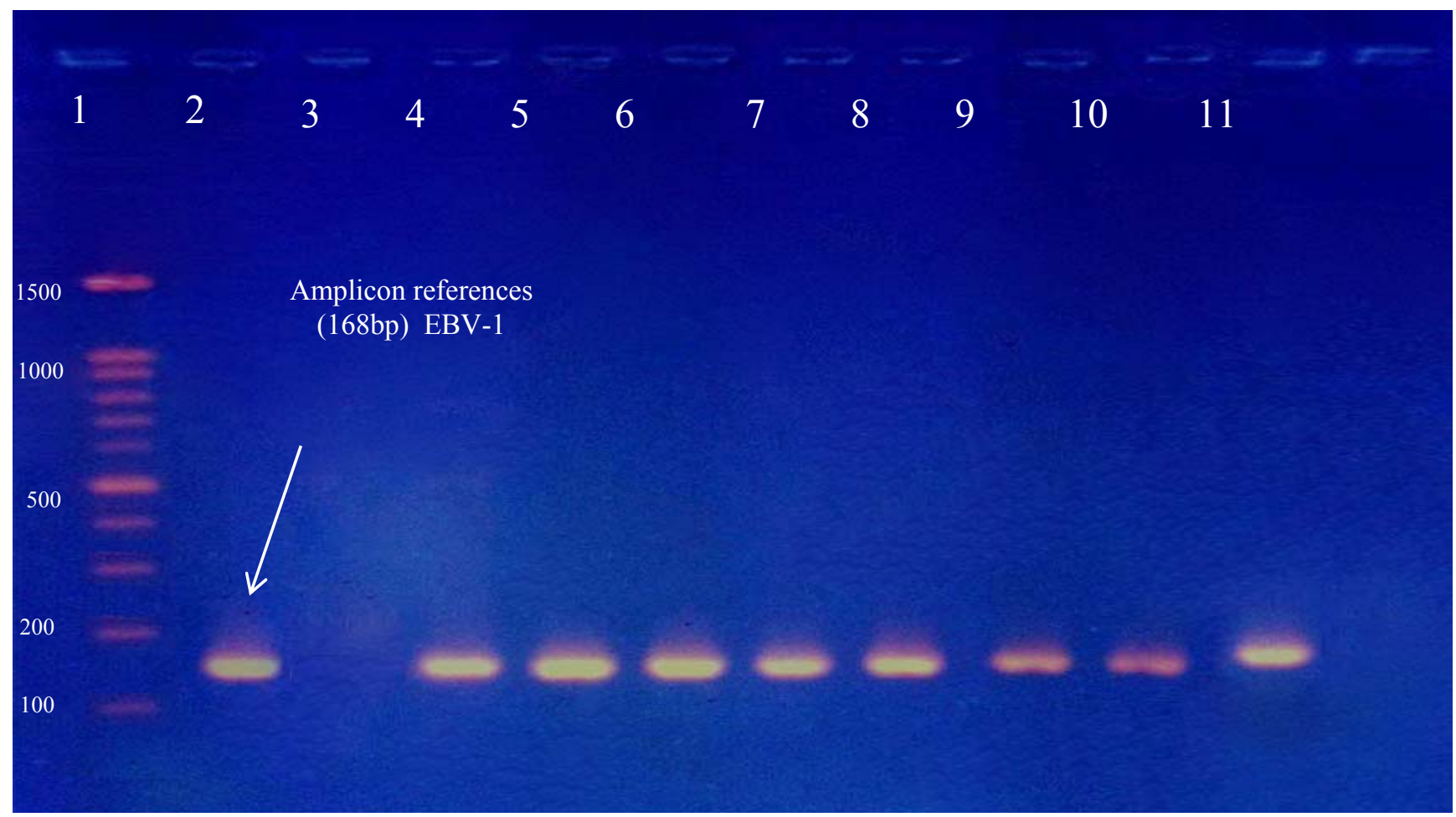

Fig. 1: Ethidium bromide-stained agarose gel of PCR amplified products from extracted EBV DNA amplified with primers EBNA2 gene. Lane 1 DNA molecular sizes marker (100-bp. ladder). Lanes (2-11) EBV extracted show positive results for EBNA2 gene (amplicon size 168 bp.).

\section{DISCUSSION}

In the 1970s, IARC demonstrated that more than $90 \%$ of adults worldwide are infected with EBV, based on the detection of antibodies to EBV especially antibodies to viral capsid (VCA) and complement-fixing soluble (CF/S) antigens (IARC, 1997). On one side the results of the present study agree with Kannangai et al., (2010), who documents that autoimmune diseases have been positive for EBV and on the other side, our study disagrees with the recent study on EBV in rheumatoid arthritis that shows a higher positivity of antiEBV compared to controls (Balandraud et al., 2005; Balandraud et al., 2003). In patients with rheumatoid arthritis (RA), the immune response to the EBV is slightly impaired, which usually have high titer anti-EBV antibodies in their sera, and also have impaired peripheral blood T-cell responses to EBV proteins. This can result in inefficient control of the outgrowth of EBV infected B cells and systemic EBV overload (Balandraud et al., 2005). Subsequent studies have shown that $99 \%$ of SLE patients are seropositive for EBV (James et al., 2001). SLE patients have higher titers of anti-EBV antibodies than control populations (Verdolini et al., 2002). T cells from patients with SLE cannot control the numbers of EBV-infected B cells from SLE patients or normal subjects but $\mathrm{T}$ cells from normal EBV-seropositive subjects can control infected B cells from SLE patients (Tsokos et al., 1983). Patients with autoimmune thyroiditis have increased titers of antiEBV antibodies in their sera compared to healthy subjects (Vrbikova et al., 1996). As well Jasim, (2010) who found that the highly titer of IgG antibodies to EBV-VCA in Hashimoto's and Graves' disease as compared with healthy people. On the other hand, a previous study shows about $15 \%$ of thalassemia patients have EBV DNA whom are on 
frequent transfusion treatment (Ergazaki et al., 1994), suggested that EBV can be transmitted via transfussion of blood or blood products given and/or bone marrow transplantation (Liloglou et al., 1994). In one side Arjmandi et al., (2008) conducted a study on EBV in beta thalassemia and he documents that thalassemic patients show positivity of Anti-EBV (0.75\%). On the other side, Papaevangelou et al., (1979) who document that there are no evidence of repeated infection or recent infection with EBV in the polytransfused thalassemia patients.

Moreever, The low income and crowded family conditions have also been found to increase titer of EBV seropositive in children from other geographical locales, such as Thailand (Mekmullica et al., 2003), Turkey (Ozkan et al., 2003).

On the other hand, antibody titers seem to be higher in females than in males (Wagner et al., 1994). This difference, which also has been observed for other viruses, is in accordance with the notion that women in general mount more vigorous antibody- and cellmediated immune response following infection or vaccination than men (Beagley and Gockel, 2003).

Generally, two major types of EBV (EBV-1 and EBV-2) have been identified and differ in geographic distribution. The role of specific EBV types in the etiology of different cancers is unknown. Immunocompromised patients are more commonly harbour both subtypes of EBV (Thompson and Kurzrock, 2004). In the present study, EBV-1 was predominant. This is consistent with the previous studies, Abdirad et al., (2007) report that type $1 \mathrm{EBV}$ is predominant in Iran and with other previous studies that reveal that type 1 EBV is the most prevalent in Asia (Sidagis et al., 1997), An interesting finding is the high frequency of EBV type -2 with latent membrane protein-1 (LMP-1) deletion in the Mexican and found a similar prevalence of EBV diffuse large B-cell lymphoma of the elderly in a Mexican population compared with that has been reported from Asian countries, and in contrast to the low frequency in Western populations (Hofscheier et al., 2011). Type $2 \mathrm{EBV}$ is predominant in equatorial Africa (Yao et al., 1996) and the high incidence of type 2 EBV infections among HIV positive patients especially during the first 10 years of the AIDS epidemic (Biggar and Rabkin, 1996). EBV-2 may be more common in Africa (Gratama and Ernberg, 1995), and in homosexual men (Higgins et al., 2007). However, other studies show that HIV-infected haemophiliacs have lower rates of EBV-2 infection than HIV-infected homosexuals have challenged this hypothesis, and suggest that the acquisition of EBV-1 versus EBV-2 would rather be due to the opportunity for exposure (Thompson and Kurzrock, 2004). However, we need first to evaluate the genotype of EBV in healthy people and more advanced research in Iraq before any conclusion.

\section{REFERENCES}

Abdirad, A.; Ghaderi-Sohi, S.; Shuyama, K.; Koriyama, C.; Nadimi-Barforoosh, H.; Emami, S.; Mosavi-Jarrahi, A.; Nahvijou, A.; Akiba, S. (2007). Epstein-Barr virus associated gastric carcinoma: a report from Iran in the last four decades. Diagnostic Pathology, 2, 25.

Arjmandi, R.K.H.; Vossough, P.; Eivazzadeh, B. (2008). Prevalence of viral infection in beta thalassemia patients. Arch. Dis. in Childhood, 93, 129. 
Balandraud, N.; Roudier, J.; Roudier, C. (2005). What are the links between Epstein-Barr virus, lymphoma, and tumour necrosis factor antagonism in rheumatoid arthritis? Semin Arthr. Rheum., 34(1), 31-33.

Balandraud, N.; Roudier, J.; Roudier, C. (2004). Epstein Barr Virus and rheumatoid arthritis. Autoimmun Rev., 3, 362-367.

Balandraud, N.; Meynard, J.B.; Auger, I.; Sovran, H.; Mugnier, B.; Reviron, D.; Roudier, J.; Roudier, C. (2003). Epstien-Barr virus load in the peripheral blood of patients with rheumatoid arthritis: accurate quantification using real-time polymerase chain reaction. Arthritis Rheum, 48,1223-1228.

Beagley, K.W.; Gockel, C.M. (2003). Regulation of innate and adaptive immunity by the female sex hormones oestradiol and progesterone. FEMS Immunol. Med. Microbiol., 38(1),13-22.

Biggar, R.J.; Rabkin, C.S. (1996). The epidemiology of AIDS-related neoplasms. Haematol Oncol. Clin. North. Am., 10, 997-1010.

Ergazaki, M.; Xinarianos, G.; Giannoudis, A.; Koffa, M.; Liloglou, T.; Kattamis, Ch.; Spandidos, D.A. (1994). Detection of human cytomegalovirus and Epstein-Barr virus by the polymerase chain reaction in patients with $\beta$-thalassaemia. Oncology Reports, 1, 813-816.

Evans, S. (1971). E.B. virus antibody in systemic lupus erythematosus. Lancet 1,10231024.

Gratama, J.W.; Ernberg, I. (1995). Molecular epidemiology of Epstein-Barr virus infection. Adv. Cancer Res., 67, 197-255.

Higgins, C.D.; Swerdlow, A.J.; Macsween, K.F.; Harrison, N.; Williams, H.; McAulay, K.; Thomas, R.; Reid, S.; Conacher, M.; Britton, K.; Crawford, D.H. (2007). A study of risk factors for acquisition of Epstein-Barr virus and its subtypes. J. Infect. Dis., 195, 474-482.

Hofscheier, A.; Ponciano, A.; Bonzheim, I.; Adam, P.; Lome-Maldonado, C.; Vela, T.; Cortes, E.; Ortiz-Hidalgo, C.; Fend, F.; Quintanilla-Martinez, L. (2011). Geographic variation in the prevalence of Epstein-Barr virus-positive diffuse large B-cell lymphoma of the elderly: a comparative analysis of a Mexican and a German population. Modern Pathology, 24, 1046-1054.

IARC (1997). Epstein-barr virus and Kaposi's sarcoma herpesvirus / Human herpesvirus 8. IARC Monogr Eval Carcinog Risks Hum, 70, 1-492.

James, J.A.; Neas, B.R.; Moser, K.L.; Hall, T.; Bruner, G.R.; Sestak, A.L.; Harley, J.B. (2001). Systemic lupus erythematosus in adults is associated with previous EpsteinBarr virus exposure. Arthritis Rheum., 44, 1122-1126.

Jasim, B.S. (2010). Serological study on Epstein Barr virus in some autoimmune thyroid diseases. MSc. Thesis. College of Health and Medical Technology, Foundation of Technical Education, Iraq.

Jin, Y.; Xie, Z.; Lu, G.; Yang, S.; Shen, K. (2010). Characterization of variants in the promoter of BZLF1 gene of EBV in nonmalignant EBV-associated diseases in Chinese children. Virolo. J., 7, 92.

Kannangai, R.; Sachithanandham, J.; Kandathil, A.J.; Ebenezer, D.L.; Danda, D.; Vasuki, Z.; Thomas, N.; Vasan, S.K.; Sridharan, G. (2010). Immune responses to 
Epstein-Barr virus in individuals with systemic and organ specific autoimmune disorders. Ind. J. Med. Microbiol., 28(2),120-3.

Kieff, E.; Liebowitz, D. (2001). "Epstein-Barr Virus and its Replication". In: Fields BN, Knipe DM, Howley P, editors. Fields virology. New York, Raven Press, pp. 1889-1920.

Liloglou,T.; Giannoudis, A.; Ergazaki, M.; Koffa, M.; Spandidos, D.A. (1994). Detection of Epstein Barr virus by the polymerase chain reaction in immunosuppressed and immunocompromised patients. Oncol. Rep., 1, 809-811.

Mekmullica, J.; Kritsaneepaiboon, S.; Pancharoen, C. (2003). Risk factors for Epstein-Barr virus infection in Thai infants. Southeast Asian J. Trop. Med. Public Health, 34(2),395-397.

Middeldorp, J.M.; Brink, A.A.; van den Brule, A.J.; Meijer, C.J. (2003). Pathogenic roles for Epstein-Barr virus (EBV) gene products in EBV-associated proliferative disorder. Crit. Rev. Oncol. Hematol., 45, 1-36.

Morissette, G.; Flamand, L. (2010). Herpesviruses and chromosomal integration. J. Virol., 84, 12100-12109.

Ozkan, A.; Kilic, S.S.; Kalkan, A.; Ozden, M.; Demirdag, K.; Ozdarendeli, A. (2003). Seropositivity of Epstein-Barr virus in Eastern Anatolian Region of Turkey. Asian Pac. J. Allergy Immunol., 21(1), 49-53.

Papaevangelou, G.; Economidou, J.; Roumeliotou, A.; Adrachta, D.; Parcha, S. (1979). EpsteinBarr virus infection in polytransfused patients with homozygous beta-thalassaemia. Vox Sang., 37(5), 305-309.

Pender, M.P. (2003). Infection of auto reactive B lymphocytes with EBV, causing chronic autoimmune diseases. Trends Immunol. 24,584-588.

Poole, B.D.; Scofield, R.H.; Harley, J.B.; James, J.A. (2006). Epstein-Barr virus and molecular mimicry in systemic lupus erythematosus. Autoimmunity, 39, 63-70.

Rickinson, A.B.; Kieff, E. (2001). "Epstein-Barr Virus. In Fields Virology". V. 2. 4th ed. Edited by: Knipe, D.M.; Howley, P.M.; Griffin, D.E.; Lamb, R.A.; Martin, M.A.; Roizman, B.; Straus, S.E.; Philadelphina, Lippincott Williams and Wilkins; pp. 25752628.

Sidagis, J.; Ueno, K.; Tokunaga, M.; Ohyama, M.; Eizuru, Y. (1997). Molecular epidemiology of Epstein-Barr virus (EBV) in EBV-related malignancies. Int. J. Cancer., 72, 72-76.

Thompson, M.P.; Kurzrock, R. (2004). Epstein-Barr virus and cancer. Clin. Cancer Res, 10, 803-821.

Tsokos, G.C.; Magrath, I.T.; Balow, J.E. (1983). Epstein-Barr virus induces normal B cell responses but defective suppressor $\mathrm{T}$ cell responses in patients with systemic lupus erythematosus. J. Immunol., 131, 1797-1801.

Verdolini, R.; Bugatti, L.; Giangiacomi, M.; Nicolini, M.; Filosa, G.; Cerio, R. (2002). Systemic lupus erythematosus induced by Epstein-Barr virus infection. Br. J. Dermatol., 146, 877-881.

Vrbikova, J.; Janatkova, I.; Zamrazil, V.; Tomiska, F.; Fucikova, T. (1996). Epstein-Barr virus serology in patients with autoimmune thyroiditis. Exp. Clin. Endocrinol., 104, 89-92.

Wagner, H.J.; Hornef, M.; Teichert, H.M.; Kirchner, H. (1994). Sex difference in the serostatus of adults to the Epstein-Barr virus. Immunobiology., 190(4-5), 424-429.

Yao, Q.Y.; Tierney, R.J.; Croom-Carter, D.; Dukers, D.; Cooper, G.M.; Ellis, C.J.; Rowe, M.; Rickinson, A.B. (1996). Frequency of multiple EBV infections in T-cellimmunocompromised individuals. J. Virol., 70, 4884-4894. 